\title{
REVIEW
}

\section{USE OF EVALUATION TOOLS TO EVALUATE SYMPTOMS AND CHANGES IN CLIMACTERIC WOMEN IN THE CZECH REPUBLIC AND ABROAD}

\author{
Romana Belešová, Valérie Tóthová \\ Institute of Nursing, Midwifery and Emergency Care, Faculty of Health and Social Sciences, University of South Bohemia in \\ České Budějovice, Czech Republic
}

Received February 18, 2019; Accepted November 12, 2019. Copyright: This is an open access article distributed under the terms of the Creative Commons Attribution International License (CC BY). http://creativecommons.org/licenses/by/4.0/

\begin{abstract}
Aim: The paper surveys empirical research on the use of evaluation tools with the purpose of evaluating symptoms and changes in climacteric women in the Czech Republic and other countries. In order to evaluate the range of individual symptoms, a great number of standardized questionnaires and measuring scales have been created, which are logically designed for clear statistic evaluation, and are used on a global scale to measure the severity of disorders, or quality of life of women. Design: A literature review. Methods: In outline, the article is an overview making use of content analysis of studies published in scientific databases, e.g. EBSCO, PubMed, ProQuest, and ScienceDirect, during the years 2012 to 2018. The overview focuses on articles dealing with the use of evaluation tools in connection with menopause. After screening for eligibility, 25 articles were eventually analyzed. Results: Following analysis of the results of foreign empirical research, it was apparent that the most common evaluation tool for defining the types and level of symptoms in climacteric women was the Menopausal Rating Scale. Besides this tool, other tools, such as the Greene Climacteric Scale, the Kuperrman index, the Menopause-Specific Quality of Life Questionnaire, the Women's Health Questionnaire, and the Utian Quality of life Scale were used in this field. Two studies focusing on the Czech Republic were analyzed. The standardized tool used in these cases was the Menopausal Rating Scale. Conclusion: A number of foreign studies have been conducted regarding climacteric women monitoring symptoms and changes in psychological condition and behaviour, and changes in their cognitive and emotional states, or evaluating their quality of life. However, only two such studies have been undertaken in the Czech Republic.
\end{abstract}

Keywords: climacteric (menopause), quality of life, rating scale, symptom, woman.

\section{Introduction}

During the $20^{\text {th }}$ century the life expectancy of women lengthened, on average, by 30 years. However, since the age at which ovarian function ceases has not changed, the period of oestrogen deficiency has significantly increased (Fait, 2013). The recent increase in the number of middle-aged and elderly women has resulted in an increasing number of women experiencing a long part of their lives in oestrogen deficiency. An increasing number of women will live with the consequences of loss of sexual hormones to the age of eighty or more (Dostál, Turková, 2017). Although the length of women's lives after menopause has increased (representing 1/3 of a woman's life), the mean age of menopause (52.5 years) has been the same since antiquity (Al-Musa et al., 2017). Women in ancient Greece experienced menopause at the same age as women nowadays (with occurrence of symptoms

Corresponding author: Romana Belešová, Institute of Nursing, Midwifery and Emergency Care, Faculty of Health and Social Sciences, University of South Bohemia in České Budějovice, $U$ Výstaviště 26, České Budějovice, Czech Republic; e-mail: rbelesova@zsf.jcu.cz. starting between the ages of 45.5 to 47.5) (Fait, 2013). Factors which can decrease climacteric age include: smoking, having a hysterectomy, autoimmune defects, fragile chromosome $\mathrm{X}$, and life at high altitude (Dostál, Turková, 2017). Gonçalves et al. (2016) mention biological factors (hypoestrogenism), mental factors, and life-style factors as causing symptoms and changes in climacteric women. In addition to "natural menopause", "induced menopause" occurs when the ovaries are surgically removed (surgical menopause), or when irreversible damage is done to the ovaries, for example, as a result of radiation treatment or chemotherapy (Da Silva, d'Andretta Tanaka, 2013).

During the menopause, when women stop menstruating, they undergo the transition from the reproductive phase to the phase of reproductive rest (Stuenkel et al., 2015). During the climacteric period we distinguish the following phases: pre-menopause, menopause, post-menopause, and senium (Mackey et al., 2014). AlQuaiz, Tayel, Habiba (2013) define menopause as a gradual physiological process that occurs between the ages of 47 and 55. In this period, the absence of menstrual bleeding for the period of 12 consecutive months (with the exception of any pathological and physiological causes) is observed. 
The prevalence of signs varies according to the phases of the menopause, and, moreover, their occurrence is influenced by women's individual characteristics their sensitivity, culture, and ethnicity. According to Vural and Yangin (2017), physiological menopause occurs between 45 and 60 years of age.

Oestrogen deficiency causes a number of undesirable signs in women, both functional and organic in nature (Gonçalves et al., 2016), including vasomotor signs (hot flashes, night sweats), further loss of bone mass, urogenital atrophy, infections of the urinary tract, urinary incontinence, somatic symptoms, sexual dysfunction, loss of skin elasticity, sleeping disorders, memory loss, increased weight, and muscle and joint aches (AlQuaiz, Tayel, Habiba, 2013).

Hot flashes are regarded as the most common climacteric symptom, mentioned by $75 \%$ of peri- and post-menopausal women (they sometimes occur for just a few months, but in some cases, can persist for a number of years, and may cause discomfort, mood swings, and sleep deprivation (Liu et al., 2014). Besides hot flashes, other cardiovascular and neurological symptoms may occur (palpitation, nausea, slight headaches, dizziness) (Dostál, Turková, 2017).

The menopause and its symptoms and changes in women are related to quality of life. Quality of life is associated with concepts such as human needs, health, self-care, well-being, daily activities, and existential dimensions of human life (Gurková, 2011). The quality of human life is dependent on health, feelings of satisfaction, and human relationships, and it is perceived as a dynamically developing process, influenced by many factors. It is part of our social life, and in terms of nursing and midwifery, it represents a measure, as well as a goal, of the care provided (Hudáková, Majerníková, 2013).

Affected by the aforementioned endocrinal, mental, organic, and metabolic changes (that are part of the aging process), the menopause represents a relatively long and significant period in the life of a woman; a period when quality of life can worsen. Individual differences are evident in experience and perception of change during menopause, affecting quality of life of individual women to different degrees. In the context of nursing research, a heterogeneous spectrum of tools exists for measuring quality of life (Gurková, 2011).

The complex care of climacteric women should include monitoring of changes in mental state, behavior, cognitive and emotional components, and, at the same time, assessment of quality of life as affected by climacteric symptoms (Moravcová, 2011).

A number of standardized questionnaires and measuring scales have been developed to assess the range of individual symptoms in climacteric women. The tools are logically designed to enable clear statistical evaluation, and are used worldwide to assess quality of life, the severity of symptoms, and ways to influence them (Fait, 2013).

\section{Aim}

The aim of the paper was to survey the conclusions of empirical studies dealing with symptoms and changes in women during menopause (in the Czech Republic and abroad), and also to identify and describe individual measuring tools used to diagnose symptoms, changes and quality of life in climacteric women. A variety of symptoms appear in this very demanding period which can, to a greater or lesser extent, affect quality of life. We decided to analyze the issue of menopause and its related symptoms and changes. Standardized questionnaires and measuring scales have been designed for the purposes of evaluating type and range of individual symptoms. Constructed logically for worldwide use, they allow clear statistical evaluation to be used to evaluate the severity of disorders, and quality of life.

In our study we posed the following question: Which symptoms and changes identified using the measuring tools are responsible for diminishing women's quality of life?

\section{Methods}

\section{Design}

A literature review.

\section{Eligibility criteria}

In our selection we included articles published between 2012 and 2018. There were 328 articles published in this period. The articles were published in English, and focused on the climacteric period in women (i.e., on symptoms and level of quality of life). The articles also dealt with the use of evaluation tools for defining the type and severity of symptoms, and for measuring quality of life in climacteric women.

\section{Search strategy}

For the purpose of meeting the objectives of our article a secondary data analysis was carried out. The databases EBSCO, PubMed, ProQuest, and ScienceDirect were studied.

The following key words: "rating scale", "climacteric" ("menopause"), "quality of life", "woman" - and the Boolean operator "AND" - were used.

\section{Study selection inc. PRISMA flow diagram}

The paper takes the form of an overview study. Content analysis was used to process articles. 
The overview also included full text of sub-studies and discussion posts, and included documents that characterized the climacteric period in women (together with symptoms and changes) and the use of measuring tools for the purpose of objectification of changes accompanying this period. The studies

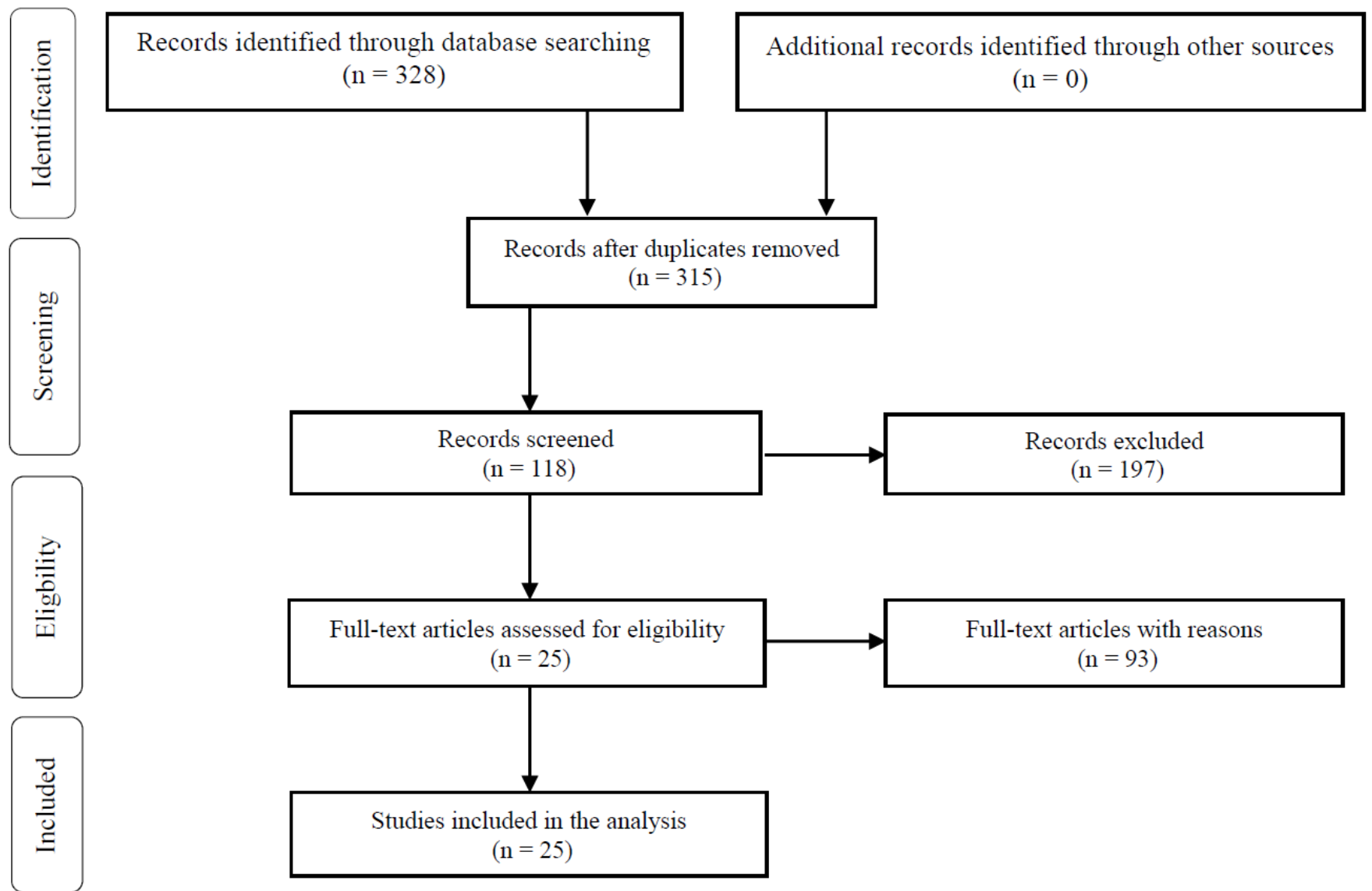

Figure 1 Flow diagram of the exlusion process recommented by the PRISMA

\section{Evaluation of quality of articles}

During the first phase of searching, 328 studies were found. In the following phase of analysis the number of studies was reduced by removing duplicate studies, studies that did not deal with a specified range of problems, and studies that did not correspond with the set criteria. Similarly, posts that were not available as full text documents, and documents that, after detailed analysis, did not contain a sufficient amount of relevant information were excluded. The sources were selected from academic periodicals.

\section{Data extraction}

The final number of relevant sources amounted to 25 texts. The studies obtained were translated and processed for the purpose of identifying any aspects relating to evaluation tools measuring the symptoms and domains of women affected by oestrogen were selected and classified according to PRISMA (evaluation standard) recommendations, as illustrated in Figure 1. The level of evidence was evaluated in line with Moher et al. (2015) recommendations.
Additional records identified through other sources $(\mathrm{n}=0)$ 
into three main domains: vasomotor, psychological, and somatic (Greene, 1998).

The Kupperman index (KI) is used, in particular, to assess individual symptoms, such as hot flashes, increased sweating, sleep disorders, irritation, depression, dizziness, headaches, concentration disorders, pains in joints, and palpitations (Capistrano et al., 2015).

The Menopause Rating Scale (MRS) consists of items assessing symptoms of climacteric women divided into subgroups - somatic symptoms, psychological symptoms, and urogenital symptoms (Heinemann et al., 2004). The MRS has become an internationally recognised rating scale. The first translation from the German original was to English (Schneider et al., 2000a), and other versions in Portuguese, French, Indonesian, Italian, Spanish, Swedish, and Turkish are available (Heinemann, Potthoff, Schneider, 2003). According to Fait (2013), the MRS is a rating scale for evaluating climacteric complaints, available in 27 languages (Moravcová, Mareš, Ježek, 2014).

The Menopause-Specific Quality of Life Scale (MENQOL) contains items divided into four domains: the vasomotor domain, the psychosocial domain, the physical domain, and the sexual domain (Ghazanfarpour et al., 2013).

The Utian Quality of Life Scale (UQoLS) is a Short Form-36 questionnaire adapted by Professor Utian, emphasizing the influence of climacteric syndrome (Fait, 2008).

The Women's Health Questionnaire (WHQ) - was developed in order to ascertain women's health state (Hunter, 2003). It covers nine domains: depressive mood, somatic symptoms, anxiety/fear, vasomotor symptoms, sleep complaints, sexual behaviour, menstruation symptoms, memory/concentration, and attractiveness. The WHQ is used in a wide range of studies. It forms part of preventive interventions for women in perimenopause and postmenopause in Europe, Australia and North America (Hunter, 2000).

\section{Studies focusing on the standardization and validation of rating scales}

Our survey focused on foreign studies concerned with the standardization and validation of measuring tools. Heinemann, Schneider (2003) compared acquired data from various studies and provided an overview of psychometric and other methodological characteristics of measuring tools for the evaluation of menopause. The MRS, designed to be a "selfadministered" scale, was standardized and has spread worldwide (Heinemann, Schneider, 2003). According to Potthoff et al. (2000), the MRS was developed in the early $1990 \mathrm{~s}$ in response to the shortage of standardized tools for measuring the severity of aging symptoms (periodic sweating or hot flashes, memory disorders, lack of concentration, nervousness, depression, insomnia, and pains in joints and bones) and their impact on the health quality of life (HRQoL). The first version of the questionnaire was originally intended to be completed by gynaecologists. However, methodological criticism resulted in the development of a new tool which could also be completed by patients alone (Potthoff et al., 2000). At the beginning of the $21^{\text {st }}$ century, the MRS was validated and developed as a tool for measuring health-related quality of life (HRQoL). The aim was: a) to assess symptoms in aging women under various conditions; b) to evaluate the severity of symptoms over the course of time; c) to measure the changes in substitution therapy before and after treatment (Potthoff et al., 2000; Schneider et al., 2000; 2000a; 2000b). Chaikittisilpa et al. (2013) describe a study performed between 2009 and 2011 dealing with climacteric aspects in peri- and postclimacteric Thai women. The goal was to develop and validate a standardized questionnaire (MS-QoLS). The evaluation of this questionnaire demonstrated acceptable validity and reliability for this ethnic group. In addition, we acquired information on a study carried out in the Czech Republic, the aim of which was to create a Czech version of the MRS questionnaire. Moravcová, Mareš, Ježek (2014) set the goal of surveying the psychometric properties of the MRS and testing their suitability for use in clinical practice in a Czech context. By repeated and reverse translation, a Czech version of the MRS was developed (tested on a sample of 204 women after natural menopause, aged 49-63 years). This version can be used for an approximate assessment of quality of life of women in postmenopause, and, in addition, it enables assessment of the range of climacteric symptoms, their intensity, and possible therapeutic effects. The tool has 11 items (as does the original MRS), divided into three domains (somatic and vegetative, psychological, and urogenital) (Moravcová, Mareš, Ježek, 2014). In the Czech version, the period described in the original version as "recently" (Heinemann et al., 2004) was changed to "in the last month" (Moravcová Mareš, Ježek, 2014), since, according to Moravcová, Mareš, Ježek (2014), an evaluation of a specified period helps women to be more precise about their current condition.

For an overview of the information acquired from the various studies, focusing on the use of evaluation tools in climacteric women, see Table 1 below (Part 1-2). 


\section{Muscle and joint aches in climacteric women}

In our study of menopause and the use of evaluation tools, we paid particular attention to studies focusing on muscle and joint pain in women, since these types of pain often reduce quality of life. A summarizing study conducted in 18 towns in 12 South American countries, including 8,373 women aged 40-59 years, explored whether pain in muscles and joints was related to hormonal changes in menopause. The MRS was used as the tool for surveying quality of life (Blümel et al., 2013). The prevalence of muscle and joint aches was relatively high, and correlated significantly to menopause, particularly to vasomotor symptoms occurring in women in this period (Blümel et al., 2013).

In their study performed in India in 2011, Joseph et al. (2014) focused on muscle and joint pains in 110 women aged $40-65$ years. The aim of the study was to assess the occurrence and severity of climacteric symptoms using the MRS, and to identify factors influencing climacteric symptoms. The most common symptoms, such as muscle and joint aches, were identified, including physical and psychological urogenital symptoms, (Josepf et al., 2014).

In another study dealing with the issues mentioned above, AlQuaiz, Tayel, Habiba (2013) focused on the evaluation of climacteric symptoms of Arabic women living in Saudi Arabia. The MRS was used to rate climacteric symptoms and their severity. This study compared symptoms such as muscle and joint problems $(83.3 \%$ of women), physical and psychological exhaustion (80.2\%), sleep problems $(71.2 \%)$, irritation, and psychological complaints (71.0\%). The number of women who mentioned hot flashes and night sweats was comparable to that of women from Western countries (AlQuaiz, Tayel, Habiba, 2013).

Between January and March, 2016, Al-Musa et al. (2017) (also from Saudi Arabia) studied (using the standardized MRS) how social and demographic factors, culture, and lifestyle can influence the perception of climacteric symptoms, and how these symptoms affect quality of life in these women. The results indicated that $96.1 \%$ of respondents complained of joint and muscle problems; while irritation $(94.7 \%)$, anxiety $(89.0 \%)$, and hot flashes and sweating $(80.7 \%)$ were also reported (Al-Musa et al., 2017).

The Beck Anxiety Index and the Pittsburgh Sleep Quality Index (PSQI) are other commonly used rating scales used in association with menopause (Haliloğlu, Uzkeser, İçăgasioğlu, 2014). In their study performed in Turkey using these tools, Haliloğlu, Uzkeser, İcağasioğlu (2014) assessed the effects of backache on sleep quality, quality of life, and depression in women with post-climacteric osteoporosis, and confirmed the hypothesis that pain, depression, and sleep problems impaired quality of life.

\section{Studies focusing on metabolic syndrome}

According to Lee et al. (2012), metabolic syndrome was identified in $25 \%$ of middle-aged women, and obesity, its main component, contributes to the increasing prevalence and severity of climacteric women's complaints. Chedraui et al. (2014) based their study on the data provided by Lee et al. (2012). The study was performed in Ecuador between December, 2011, and June, 2012, and surveyed the occurrence and severity of climacteric complaints in 204 women aged 40-65, in post-menopause. Chedraui et al. (2014) focused, in particular, on obesity, assessing (using a screening program examination of the metabolic syndrome) the effect of obesity on the intensity of climacteric complaints. The MRS was used to evaluate the symptoms. The results did not indicate any significant influence of metabolic syndrome and obesity on the prevalence and severity of climacteric symptoms (Chedraui et al., 2014)

Another study, described by Gonçalves et al. (2016), focused on testing the correlation of overweight/obesity in menopause and climacteric symptoms, using the MRS to assess climacteric symptoms. Two hundred and fifty-three women participated in this study, performed in Brazil in 2013. In addition to the effect of overweight on the higher prevalence of climacteric complaints, biological factors (hypooestrogenism), psychosocial factors, and lifestyle factors were indicated (Gonçalves et al., 2016).

Ghazanfarpour et al. (2013) also investigated whether body mass index (BMI), abdominal obesity, or fat distribution influence quality of life in postclimacteric women. The study was conducted in Iran, and included 233 sexually active women (aged 45-70 years) with intact vaginal mucosa and ovaries. The women underwent anthropometric measurement, the results of which were recorded. They were also interviewed using the MENQOL. The MENQOL results indicated that obese women had more complaints in the physical domain; that women with android type of fat had higher scores in vasomotor and physical domains; and that while obesity did not affect general quality of life, its influence in the psychological domain was obvious (Ghazanfarpour et al., 2013).

The aim of a study by Capistrano et al. (2015) was to identify sociodemographic and anthropometric profiles, and to correlate them with the severity 
of climacteric symptoms in postmenopausal women. A summarizing study was performed with 201 women in Brazil in 2013, and the KI was used to rate their complaints (focusing particularly on current complaints). The results indicated that obesity in respondents did not correlate with menopausal symptoms. However, moderate to severe complaints were associated with respondents' age. An almost 1.4 times higher prevalence of severe complaints was found in women who had experienced menopause in the previous 6-10 years than in those who had experienced menopause more than 10 years before (Capistrano et al., 2015).

\section{Studies focusing on the urogenital system in women}

DiBonaventura et al. (2014) describe an internet study focusing on vulvo-vaginal atrophy associated with menopause. The study defined vulvovaginitis symptoms using the MRS. The study was performed in 2010 and included women aged 45-70 in the USA (3,267 women), Germany (970 women), Italy (387 women), the United Kingdom (1,096 women), Spain (294 women), and France (1,054 women). The symptoms of vulvovaginitis have been proven to be associated with a considerable and clinically significant decrease in quality of life (DiBonaventura et al., 2014). Another summarizing study, dealing with climacteric complaints associated with sexuality, was conducted in women aged 40-60 years in Iran in 2012, revealing a correlation between the severity of somatic and urogenital symptoms, and sexual dysfunction (Eftekhar et al., 2016).

\section{Studies focused on women's psychology}

In Brazil, between July 2011, and January 2012, a summarizing study was conducted among 1,415 women aged 35-65 years to identify the frequency and severity of menopausal factors (Da Silva, d'Andretta Tanaka, 2013). Besides the MRS, the KI and the Greene Climacteric Scale were used. Analysis of the data indicated that quality of life of women in Brazil had been impaired predominantly by psychological complaints. The impact of socioeconomic aspects on women's health and menopausal state was also detailed (Da Silva, d'Andretta Tanaka, 2013).

Wariso et al. (2017) describe another study which was performed in the USA between 1999 and 2014, including women aged 40-60 years who had registered depression and amenorrhoea in their case history for at least six months (and no longer than one year). In this study, quality of life, social adjustment, and health problems of women with depression in their case histories were compared with women without depression, using the standardized Quality of Life Enjoyment Scale Questionnaire (Q-LES-Q-SF), the Sheehan Disability Scale, and the Social
Adjustment Scale. According to Wariso et al. (2017), neither the state of women in perimenopause nor hot flashes had any significant impact on quality of life since their quality of life had already been significantly reduced by their underlying diagnosis, i.e. depression.

Abdelrahman, Abushaikha, al-Motlaq (2014) studied perceptions of the level of stress connected with menopausal symptoms among women aged 40-55 years in Jordan (using the Greene Climacteric Scale GCS). They found that although perimenopausal women did not report a high level of psychological comfort (they were experiencing stress), this had not been influenced by menopause. Meanwhile, intensive vasomotor symptoms, and loss of interest in sex were identified in postmenopausal women (Abdelrahman, Abushaikha, al-Motlaq, 2014).

Study comparing symptoms of women of different cultures

Vural, Yangin (2017) investigated statistical differences in menopausal symptoms between 160 Turkish and 160 German women, using the MRS to evaluate symptoms. While urogenital symptoms of Turkish women increased with age; in German women somatic and psychological complaints increased. The overall study results indicated that Turkish women experienced more severe complaints than German women; differing socio-cultural characteristics played a role in this (Vural, Yangin, 2017).

Studies focusing on using alternative methods of menopause treatment and healthy lifestyles

With regard to alternative treatment methods, Liu et al. (2014) describe their multi-central randomized study, conducted in 12 Chinese hospitals between June 2013 - May 2015. They used rating scales (MRS, MENQOL, KI) to evaluate women who underwent acupuncture for eight weeks in order to reduce hot flashes and to improve their quality of life (Liu et al., 2014).

Hirose et al. (2018) mention a randomized, doubleblind, placebo-controlled study performed in women (40-60 years) in Japan from February to July, 2015, the goal of which was to identify the influence of soy lecithin on menopausal complaints. The HealthRelated Quality of Life questionnaire (MHR-QOL) was used. During the assessment, data relating to lifestyle factors, physical and psychological menopausal complaints, subjective symptoms and positive effects of high doses of soy lecithin on diastolic blood pressure reduction were identified (Hirose et al., 2018). 
Table 1 Files and methodology of analysed files (Part 1)

\begin{tabular}{|c|c|c|c|c|}
\hline $\begin{array}{l}\text { Author (year), } \\
\text { country }\end{array}$ & Type of research & Aim of the research & Research file & $\begin{array}{l}\text { Evaluation tool } \\
\text { used }\end{array}$ \\
\hline $\begin{array}{l}\text { Abdelrahman, } \\
\text { Abushaikha, al-Motlaq } \\
\text { (2014), Jordan }\end{array}$ & quantitative research & $\begin{array}{l}\text { determining perception of } \\
\text { the level of stress regarding } \\
\text { symptoms multicultural } \\
\text { factors on quality of life }\end{array}$ & $\begin{array}{l}193 \text { women } \\
\text { age } 40-55\end{array}$ & GCS \\
\hline $\begin{array}{l}\text { Al-Musa et al. (2017), } \\
\text { Saudi Arabia }\end{array}$ & $\begin{array}{l}\text { quantitative research; } \\
\text { cross-sectional study }\end{array}$ & $\begin{array}{l}\text { evaluating the affect of } \\
\text { demographic factors, } \\
\text { culture, and lifestyle on } \\
\text { climacteric symptoms }\end{array}$ & $\begin{array}{l}228 \text { women } \\
\text { age } 45-70\end{array}$ & MRS \\
\hline $\begin{array}{l}\text { AlQuaiz, Tayel, Habiba } \\
\text { (2013), Saudi Arabia }\end{array}$ & $\begin{array}{l}\text { quantitative research; } \\
\text { cross-sectional study }\end{array}$ & $\begin{array}{l}\text { comparing symptoms - } \\
\text { muscle and joint pain, } \\
\text { physical and mental } \\
\text { exhaustion, sleep } \\
\text { disturbance, irritation, } \\
\text { mental problems }\end{array}$ & $\begin{array}{l}490 \text { women } \\
\text { age } 45-55\end{array}$ & MRS \\
\hline $\begin{array}{l}\text { Blümel et al. (2013), } \\
\text { South America }\end{array}$ & $\begin{array}{l}\text { quantitative research; } \\
\text { cross-sectional study }\end{array}$ & $\begin{array}{l}\text { detecting the effect of } \\
\text { hormonal changes on joint } \\
\text { and muscle pain }\end{array}$ & $\begin{array}{l}8373 \text { women } \\
\text { age } 40-59\end{array}$ & MRS \\
\hline $\begin{array}{l}\text { Capistrano et al. } \\
(2015), \text { Brazil }\end{array}$ & $\begin{array}{l}\text { quantitative research, } \\
\text { cross-sectional study }\end{array}$ & $\begin{array}{l}\text { Detecting the effects of } \\
\text { obesity on symptoms }\end{array}$ & $\begin{array}{l}201 \text { women } \\
\text { age } 55-65\end{array}$ & Kupperman index \\
\hline $\begin{array}{l}\text { Chaikittisilpa et al. } \\
\text { (2013), Thailand }\end{array}$ & $\begin{array}{l}\text { qualitative research, } \\
\text { focus group; } \\
\text { quantitative research, } \\
\text { in-depth interview }\end{array}$ & $\begin{array}{l}\text { creation and validation of } \\
\text { a questionnaire }\end{array}$ & $\begin{array}{l}280 \text { women } \\
\text { age } 40-60\end{array}$ & MS-QoLS \\
\hline $\begin{array}{l}\text { Chedraui et al. (2014), } \\
\text { Ecuador }\end{array}$ & $\begin{array}{l}\text { quantitative research; } \\
\text { cross-sectional study }\end{array}$ & $\begin{array}{l}\text { detecting the influence of } \\
\text { obesity on symptoms }\end{array}$ & $\begin{array}{l}204 \text { women } \\
\text { age } 40-65\end{array}$ & MRS \\
\hline $\begin{array}{l}\text { Cortés-Bonilla et al. } \\
\text { (2016), Mexico }\end{array}$ & $\begin{array}{l}\text { quantitative research; } \\
\text { multicentric, } \\
\text { randomised, one-off } \\
\text { study }\end{array}$ & $\begin{array}{l}\text { detecting the effect of HST } \\
\text { on symptoms (before } \\
\text { treatment, } 6 \text { months after } \\
\text { treatment) }\end{array}$ & $\begin{array}{l}103 \text { women } \\
\text { age } 40-65\end{array}$ & GCS, UQoLS \\
\hline $\begin{array}{l}\text { Da Silva, d'Andretta } \\
\text { Tanaka (2013), Brazil }\end{array}$ & $\begin{array}{l}\text { quantitative research; } \\
\text { cross-sectional study }\end{array}$ & $\begin{array}{l}\text { determining the influence } \\
\text { of socio-economic aspects } \\
\text { on condition of climacteric } \\
\text { women }\end{array}$ & $\begin{array}{l}1,415 \text { women } \\
\text { age } 35-65\end{array}$ & $\begin{array}{l}\text { MRS, Kupperman } \\
\text { index, Green } \\
\text { Climate Scale }\end{array}$ \\
\hline $\begin{array}{l}\text { Eftekhar et al. (2016), } \\
\text { Iran }\end{array}$ & $\begin{array}{l}\text { quantitative research; } \\
\text { cross-sectional study }\end{array}$ & $\begin{array}{l}\text { focus on quantification of } \\
\text { symptoms in the field of } \\
\text { sexuality }\end{array}$ & $\begin{array}{l}151 \text { women } \\
\text { age } 40-60\end{array}$ & MRS \\
\hline $\begin{array}{l}\text { Ghazanfarpour et al. } \\
\text { (2013), Iran }\end{array}$ & $\begin{array}{l}\text { quantitative research; } \\
\text { cross-sectional study }\end{array}$ & $\begin{array}{l}\text { evaluating the influence of } \\
\text { abdominal obesity on } \\
\text { quality of life }\end{array}$ & $\begin{array}{l}233 \text { women } \\
45-70\end{array}$ & MENQOL \\
\hline $\begin{array}{l}\text { Gonçalves et al. } \\
\text { (2013), Brazil }\end{array}$ & $\begin{array}{l}\text { quantitative research; } \\
\text { cross-sectional study }\end{array}$ & $\begin{array}{l}\text { evaluating the influence of } \\
\text { obesity, biological, and } \\
\text { psychological factors, and } \\
\text { the effect of lifestyle on the } \\
\text { prevalence of symptoms }\end{array}$ & $\begin{array}{l}253 \text { women } \\
\text { age } 40-60\end{array}$ & MRS \\
\hline $\begin{array}{l}\text { Haliloğlu S, Uzkeser, } \\
\text { İçağasioğlu (2014), } \\
\text { Turkey }\end{array}$ & $\begin{array}{l}\text { quantitative } \\
\text { research }\end{array}$ & $\begin{array}{l}\text { evaluating the influence of } \\
\text { back pain on quality of } \\
\text { sleep, and depression of } \\
\text { women with post- } \\
\text { menopause osteoporosis }\end{array}$ & $\begin{array}{l}105 \text { women } \\
\text { age } 46-75\end{array}$ & $\begin{array}{l}\text { Beck Depression } \\
\text { Index, PSQI }\end{array}$ \\
\hline
\end{tabular}

UQoLS - Utian Quality Life Scale 
Table 1 File and methodology of analysed files (Part 2)

\begin{tabular}{|c|c|c|c|c|}
\hline $\begin{array}{l}\text { Author (year), } \\
\text { country }\end{array}$ & Type of research & Aim of the research & Research file & $\begin{array}{l}\text { Evaluation tool } \\
\text { used }\end{array}$ \\
\hline $\begin{array}{l}\text { Hirose et al. (2018), } \\
\text { Japan }\end{array}$ & $\begin{array}{l}\text { quantitative research; } \\
\text { randomised, double } \\
\text { blind, placebo } \\
\text { controlled study }\end{array}$ & $\begin{array}{l}\text { evaluating the influence of } \\
\text { soya lecithin on symptoms }\end{array}$ & $\begin{array}{l}96 \text { women (high } \\
\text { doses of lecithin: } \\
32 \text {; low doses of } \\
\text { lecithin: } 32 \text {; } \\
\text { placebo: } 32 \text { ) } \\
\text { age } 40-60\end{array}$ & MHR-QOL \\
\hline $\begin{array}{l}\text { Joseph et al. (2014), } \\
\text { India }\end{array}$ & $\begin{array}{l}\text { quantitative research; } \\
\text { cross-sectional study }\end{array}$ & $\begin{array}{l}\text { detecting the effect of } \\
\text { hormonal changes on joint } \\
\text { and muscle pain }\end{array}$ & $\begin{array}{l}110 \text { women } \\
\text { age } 40-65\end{array}$ & MRS \\
\hline $\begin{array}{l}\text { Kim et al. (2018), } \\
\text { Korea }\end{array}$ & $\begin{array}{l}\text { randomised, double } \\
\text { blinded, placebo } \\
\text { controlled, clinical } \\
\text { study }\end{array}$ & $\begin{array}{l}\text { studying the effectiveness, } \\
\text { safety and applicability of } \\
\text { the herbal substance } \\
\text { "Danggwijagyaksan" } \\
\text { in women with anemia in } \\
\text { their medical history }\end{array}$ & $\begin{array}{l}34 \text { women } \\
\text { age } 40-60\end{array}$ & $\begin{array}{l}\text { MRS, WHOQOL- } \\
\text { BREF }\end{array}$ \\
\hline Lee et al. (2012), Korea & $\begin{array}{l}\text { quantitative research; } \\
\text { cross-sectional study }\end{array}$ & $\begin{array}{l}\text { evaluating metabolic } \\
\text { syndrome with climacteric } \\
\text { symptoms }\end{array}$ & $\begin{array}{l}183 \text { women } \\
\text { age } 40-60\end{array}$ & MRS \\
\hline Liu et al. (2014), China & $\begin{array}{l}\text { quantitative research; } \\
\text { multicentric, } \\
\text { randomised, } \\
\text { controlled study }\end{array}$ & $\begin{array}{l}\text { evaluating the effect of } \\
\text { acupuncture on reduction } \\
\text { of specific symptoms (hot } \\
\text { flashes), increasing quality } \\
\text { of life }\end{array}$ & $\begin{array}{l}360 \text { women } \\
\text { age } 45-60\end{array}$ & $\begin{array}{l}\text { MRS, MENQOL, } \\
\text { Kupperman index }\end{array}$ \\
\hline $\begin{array}{l}\text { Moravcová, Mareš, } \\
\text { Ježek (2014), Czech } \\
\text { Republic }\end{array}$ & quantitative research & $\begin{array}{l}\text { mapping psychometric } \\
\text { MRS characteristics, } \\
\text { creation of Czech version }\end{array}$ & $\begin{array}{l}204 \text { women } \\
\text { age } 49-63\end{array}$ & MRS, UQoLS \\
\hline $\begin{array}{l}\text { Taavoni, Ekbatani, } \\
\text { Haghani (2014), Iran }\end{array}$ & $\begin{array}{l}\text { quantitative research; } \\
\text { cross-sectional study }\end{array}$ & $\begin{array}{l}\text { Evaluating demographic } \\
\text { aspects, and aspects of } \\
\text { lifestyle on symptoms }\end{array}$ & $\begin{array}{l}700 \text { woman } \\
\text { age } 50-60\end{array}$ & PSQI \\
\hline $\begin{array}{l}\text { Tranche et al. (2016), } \\
\text { Spain }\end{array}$ & $\begin{array}{l}\text { quantitative research; } \\
\text { randomised, open, } \\
\text { controlled, clinical } \\
\text { study }\end{array}$ & $\begin{array}{l}\text { determining the influence } \\
\text { of soya drink with high } \\
\text { content of isoflavones on } \\
\text { symptoms }\end{array}$ & $\begin{array}{l}147 \text { women } \\
\text { age } 40-60\end{array}$ & MRS \\
\hline $\begin{array}{l}\text { Urbánková, } \\
\text { Moravcová, Dopitová } \\
\text { (2016), Czech Republic }\end{array}$ & quantitative research & $\begin{array}{l}\text { evaluating the influence of } \\
\text { oestrogen deficiency on } \\
\text { symptoms }\end{array}$ & $\begin{array}{l}334 \text { women, } \\
\text { age } 45-60\end{array}$ & MRS \\
\hline $\begin{array}{l}\text { Vora, Dangi (2014), } \\
\text { Japan }\end{array}$ & $\begin{array}{l}\text { quantitative research; } \\
\text { controlled, } \\
\text { randomised, } \\
\text { intervention study }\end{array}$ & $\begin{array}{l}\text { evaluating the influence of } \\
\text { yoga on symptoms }\end{array}$ & $\begin{array}{l}30 \text { women } \\
\text { age } 45-55\end{array}$ & MRS, MENQOL \\
\hline $\begin{array}{l}\text { Vural, Yangin (2017), } \\
\text { Turkey }\end{array}$ & $\begin{array}{l}\text { quantitative research; } \\
\text { multi-cultural study }\end{array}$ & $\begin{array}{l}\text { evaluating the influence of } \\
\text { socio-cultural factors on } \\
\text { symptoms }\end{array}$ & $\begin{array}{l}160 \text { women } \\
\text { (Turkish ethnic } \\
\text { group) } \\
\text { age } 40-60 ; \\
160 \text { women } \\
\text { (German ethnic } \\
\text { group) } \\
\text { age } 40-60\end{array}$ & MRS \\
\hline $\begin{array}{l}\text { Wariso et al. (2017), } \\
\text { USA }\end{array}$ & quantitative research & $\begin{array}{l}\text { comparing quality } \\
\text { of life of women with } \\
\text { depression with quality of } \\
\text { life of women without } \\
\text { depression }\end{array}$ & $\begin{array}{l}41 \text { women } \\
\text { age } 40-60\end{array}$ & $\begin{array}{l}\text { Q-LES-Q-SF, SAS, } \\
\text { SDS, GAF }\end{array}$ \\
\hline
\end{tabular}


Kim et al. (2018) describe a pilot study performed in Korea in 2017, the goal of which was to survey the effectiveness of a herbal agent known as "Danggwijagyaksan" in peri- and postmenopausal women with diagnosed anemia (using the WHOQoLBREF and MRS rating scales).

Vora, Dangi (2014) examined the effects of yoga (Pranayama and Surya namaskar) on complaints and quality of life in early menopause. The results indicated that under the influence of yoga, MRS symptoms in three domains (somato-vegetative, psychological and uro-genital) were significantly reduced, and, in addition, menopausal symptoms improved considerably according to the MENQOL (Vora, Dangi, 2014).

The aim of a Spanish randomized, open and controlled study in 2012 conducted using the MRS among 147 women was to assess the effects of a soya drink, with increased content of isoflavones, on menopausal complaints of women (Tranche et al., 2016). An improvement in both somatic and urogenital symptoms, and an improvement in quality of life of women pre- and post-menopause (Tranche et al., 2016) were indicated.

Using the PSQI, a study was performed in West Teheran in 2012, investigating the effects of certain aspects of lifestyle (Taavoni, Ekbatani, Haghani, 2014). Impaired quality of sleep was identified in menopausal women (50-60 years), influenced by oestrogen deficiency, education, and occupation. No significant correlations were found between sleeping problems and personal characteristics, partner's age, number of children, or consumption of tea and coffee (Taavoni, Ekbatani, Haghani, 2014).

\section{Study focusing on the method of hormonal substitution therapy}

Cortés-Bonilla et al. (2016) mention findings from a secondary analysis of a multicentric, randomized, oneoff study conducted among 103 Mexican women. In this sample, the intensity of symptoms of menopause were evaluated before and after treatment (six months of intramuscular application of $17 \mathrm{~b}$-estradiol, progesterone). To measure the severity of symptoms, the standardized tools: the GCS, and the UQoLS were used. With women using hormonal substitution therapy, an improvement in climacteric symptoms was evident. At the same time, this lead to an improvement in quality of life (Cortés-Bonilla et al., 2016).

Study focusing on the importance of education and women's readiness to accept changes

In the Czech Republic, a significant study was conducted in the period between March - October 2015. Symptoms of oestrogen deficiency were assessed in 334 Czech women, aged 45-60 years (the MRS questionnaires were completed at gynaecological outpatient departments). The respondents most frequently reported mild complaints, or absence of certain symptoms. Symptoms of higher severity were reported particularly in somatic and vegetative domains (Urbánková, Moravcová, Dopitová, 2016). Based on the results of individual domains and the total score, the study indicated that the quality of women's lives with symptoms caused by oestrogen deficiency was influenced only to a slight degree. In addition, the importance of women's readiness to adapt and having an sufficient knowledge of climacteric changes were highlighted, as was the importance of the availability of a rating scale evaluating changes associated with menopause, so that women may be adequately helped (Urbánková, Moravcová, Dopitová, 2016).

\section{Discussion}

The goal of the paper was to describe and analyze studies dealing with the topic of the climacterium and the use of tools measuring the symptoms and changes which occur in women during it in the Czech Republic and other countries.

The survey identified studies dealing with the standardization and validation of measuring tools. In foreign studies, Heinemann, Schneider (2003) compared the data from various studies and presented an overview of tools assessing menopause. They recommended MRS as a "self-managed" scale, which had been standardized and spread worldwide. The MRS was validated in the early $21^{\text {st }}$ century (Potthoff et al., 2000; Schneider et al., 2000; 2000a; 2000b). The literature search revealed only one study focusing on the validation of the Czech version of the MRS questionnaire (Moravcová, Mareš, Ježek, 2014). In addition, Chaikittisilpa et al. (2013) developed and standardized the MS-QoLS questionnaire for Thai women.

Studies focusing on muscle and joint pain were also assessed. Joseph et al. (2014), and AlQuaiz, Tayel, Habiba (2013) mentioned the MRS as a tool to identify symptoms and changes, and to assess women's quality of life. In addition, a study conducted in South America aimed to compare fibromyalgia with various associated climacteric factors, and to determine the correlation of fibromyalgia intensity and climacteric symptoms (Blümel et al., 2013). The study showed a high prevalence of fibromyalgia in middle-aged women, significantly correlating with climacteric (particularly vasomotoric) symptoms (Blümel et al., 2013). The study by Al-Musa et al. (2017) demonstrated that Saudi Arabian women had slightly 
impaired quality of life, confirmed by higher MRS scores in other studies performed in Saudi Arabia. The respondents reported more somatic complaints (particularly joint and muscle aches) in comparison to before menopause. The study results showed that both demographic data (such as family status - widow; lower education) and lack of exercise significantly influence climacteric symptoms, and, as a result, decrease the quality of life of these women (Al-Musa et al., 2017).

Some studies also dealt with metabolic syndrome. Chedraui et al. (2014) assessed the influence of obesity on climacteric symptoms using the MRS. Their study was based on research by Lee et al. (2012), whose aim had been to survey the possible correlation and increased prevalence of metabolic syndrome as a risk factor for cardiovascular diseases associated with climacteric complaints. The study was performed in Korea in 183 women from 2008 to 2009 , using the MRS for evaluation. A higher MRS score for somatic symptoms was observed in the group of women with metabolic syndrome, and the symptoms also positively correlated with the serum level of triglycerides (Lee et al., 2012). Ghazanfarpour et al. (2013) performed anthropometric measurements in women. The level of quality of life in correlation with health (in contrast to other authors) was assessed using the MENQOL questionnaire. In obese women more physical symptoms were indicated.

In a study assessing the use of alternative methods and healthy lifestyle in climacterium treatment, Liu et al. (2014) assessed symptoms in women using the MRS, MENQOL, and KI. Liu et al. (2014) mentioned and compared results from other previous studies which had focused on influencing menopausal symptoms by means of acupuncture. One study was performed in the USA (Vincent et al., 2007), another in South Korea (Kim et al., 2010). The benefits of acupuncture regarding improvement in symptoms were not proven (Vincent et al., 2007; Kim et al., 2010). A healthy lifestyle supported by the consumption of herbal drinks has also been studied in populations of West European countries (Matthews et al., 2011), since the effects of soya isoflavones and isoflavone supplements have been put forward as an alternative to traditional hormonal treatment (Messina, 2014). Several studies confirmed the positive effect of a regular intake of isoflavones in association with a reduction in climacteric complaints, and a reduction of markers for ischemic heart disease. In addition, isoflavones were demonstrated to have a positive effect on the prevention of osteoporosis (CasteloBranco, Cancelo Hidalgo, 2011; Castelo-Branco, Soveral, 2013; Lethaby et al., 2013).
Other studies were concerned with the urogenital system (Di Bonaventura et al., 2014; Eftekhar et al., 2016), the psychology of women (Da Silva, d'Andretta Tanaka, 2013; Wariso el al., 2017), and comparison of symptoms in women from different cultures (Vural, Yangin, 2017). In addition, studies focusing on the methods of substitutional hormonal treatment (Cortés-Bonilla et al., 2016), and on the importance of women's education and readiness to embrace climacteric changes (Urbánková, Moravcová, Dopitová, 2016) were found.

Based on the literature search and content analysis of studies published in scientific databases, the MRS was identified as the most commonly used tool to assess symptoms and changes in climacteric women (both in the CR and abroad), alongside other, less frequently used measuring scales.

\section{Conclusion}

This overview of studies revealed a high number of foreign studies concerning the use of rating scales in association with both symptoms and changes in menopausal women, and their quality of life. However, during the analysis of studies published in scientific databases, only two Czech studies were found.

The analysis of articles identified the MENQOL (Ghazanfarpour et al., 2013) as the most commonly used rating scale assessing the symptoms and quality of life of menopausal women. Furthermore, other specific rating scales, such as the Greene Climacteric Scale (Cortés-Bonilla et al., 2016), the KI (Capistrano et al., 2015), the MENQOL (Vora, Dangi, 2014), the WHQ (Hunter, 2003), and the UQoLS (Cortés-Bonilla et al., 2016), were mentioned in association with the problem of quality of life in this important and demanding stage of women's lives. In addition to these tools, rating scales intended for use in a general population were mentioned, namely the Pittsburgh Sleep Quality Index (Taavoni et al., 2014), WHOQLBREF (Kim et al., 2018), Quality of Life Enjoyment Scale questionnaire, the Sheehan Disability Scale, and the Social Adjustment Scale (Wariso et al., 2017).

Considering the comparatively low number of studies using rating scales for the assessment of climacteric women in the Czech Republic, there is potential for a new study dealing exclusively with this issue.

\section{Ethical aspects and conflict of interest}

The authors state that they are not aware of any conflict of interests regarding this paper. 


\section{Acknowledgements}

The paper relates to the research grant project 058/2018/S entitled "the Use of Rating Scales in Nursing".

\section{Author contributions}

Conception and design (RB, VT), data analysis and interpretation of data $(\mathrm{RB})$, drafting the manuscript (RB), critical revision of the manuscript (VT), final completion of the article (RB, VT).

\section{References}

Abdelrahman RY, Abushaikha LA, al-Motlaq MA. Predictors of psychological well-being and stress among Jordanian menopausal women. Quality of Life Research. 2014;23(1):167-173.

Al-Musa HM, Ahmed RA, Alsamghan AS, Abadi S, AlSaleem MAS, Abdu A, Alsabaani M, Bharti RK, Alqahtani K, Alahmari S, Alshahrani H, Aboalam A, Alqahtani HA. The prevalence of symptoms experienced during menopause, influence of socio-demographic variables on symptoms and quality of life among women at Abha, Saudi Arabia. Biomedical Research. 2017;28(6):2587-2595.

AlQuaiz AM, Tayel SA, Habiba FA. Assessment of symptoms of menopause and their severity among Saudi women in Riyadh. Annals of Saudi Medicine. 2013;33(1):63-67.

Blümel JE, Chedraui P, Baron G, et al. Menopause could be involved in the pathogenesis of muscle and joint aches in midaged women. Maturitas. 2013;75(1):94-100.

Capistrano EJM, Dombek K, da Costa ACC, Figueiredo Marinheiro LP. Factors associated with the severity of menopausal symptoms in postmenopausal Brazilian women. Reprodução \& Climatério. 2015;30(2):70-76.

Castelo-Branco C, Cancelo Hidalgo MJ. Isoflavones: effects on bone health. Climacteric. 2011;14(2):204-211.

Castelo-Branco C, Soveral I. Phytoestrogens and bone health at different reproductive stages. Gynecological Endocrinology. 2013;29(8):735-743.

Chaikittisilpa S, Nimnuan C, Chirawatkal S, Jirupinyo M, Techatraisak K, Rattanachaiyanont M, Srisuparp S, Panyakhamlerd K, Jaisamrarn U, Taechakraichana N, Limpongsanurak S. Development and validation of the Menopause-specific Quality of Life Scale for menopausal Thai women. Climacteric. 2013;16(3):387-392.

Chedraui P, Pérez-López FR, Hidalgo L, Villacreses D, Dominiguez A, Escobar GS, Genazzani AR, Simoncini T; Research Group for the Omega Women's Health Project. Evaluation of the presence and severity of menopausal symptoms among postmenopausal women screened for the metabolic syndrome. Gynecological Endocrinolology. 2014;30(12):918-924.

Cortés-Bonilla M, Alonso-Campero R, Bernardo-Escudero R, Francisco-Doce MT, Chavarín-González J, Pérez-Cuevas R, Chedraui P. Improvement of quality of life and menopausal symptoms in climacteric women treated with low-dose monthly parenteral formulations of non-polymeric microspheres of 17ß- estradiol/progesterone. Gynecological Endocrinology. 2016;32(10):831-834.

Da Silva AR, d'Andretta Tanaka AC. Factors associated with menopausal symptom severity in middle-aged Brazilian women from the Brazilian Western Amazon. Maturitas. 2013;76(1):64-69.

DiBonaventura M, Luo X, Moffatt M, Bushmakin AG, Kumar $\mathrm{M}$, Bobula $\mathrm{J}$. The association between vulvovaginal atrophy symptoms and quality of life among postmenopausal women in the United States and Western Europe. Journal of Women's Health. 2015;24(9):713-722.

Dostál R, Turková M. Perimenopauza a postmenopauza. In: Pilka R et al. Gynekologie. Praha: Maxdorf; 2017. S. 65-75. (in Czech)

Eftekhar T, Dashti M, Shariat M, Haghollahi F, et al. Female sexual function during the menopausal transition in a group of Iranian women. Journal of Family and Reproductive Health. 2016;10(2):52-58.

Fait T. Možnosti objektivizace akutního klimakterického syndromu. Praktická Gynekologie. 2008;12(4):230-235. (in Czech)

Fait T. Klimakterická medicína. 2., přepracované vyd. Praha: Maxdorf; 2013. (in Czech)

Ghazanfarpour M, Abdolahian S, Zare M, Shahsavari S. Association between anthropometric indices and quality of life in menopausal women. Gynecological Endocrinology. 2013;29(10):917-920.

Gonçalves JTT, Silveira MF, Campos MCC, Rodrigues Costa LH. Overweight and obesity and factors associated with menopause. Ciência \& Saúde Coletiva. 2016;21(4):11451156.

Greene JG. Constructing a standard climacteric scale. Maturitas. 1998;29(1):25-31.

Gurková E. Hodnocení kvality života. Pro klinickou praxi a ošetřovatelský výzkum. Praha: Grada Publishing, a. s.; 2011. (in Czech)

Haliloğlu S, Uzkeser H, İçağasioğlu A. The effect of back pain on quality of life, sleep quality and depression in patients with postmenopausal osteoporosis. Türk Osteoporoz Dergisi. 2014;20(1):6-9.

Heinemann LAJ, Potthoff P, Schneider HPG. International versions of the Menopause Rating Scale (MRS). Health and Quality of Life Outcomes. 2003;1:28.

Heinemann K, Ruebig A, Potthoff P, Schneider HPG, Strelow F, Heinemann LAJ, Thai DM. The Menopause Rating Scale (MRS): a methodological review. Health and Quality of Life Outcomes. 2004;2:45.

Hirose A, Terauchi M, Osaka Y, Akiyoshi M, Kato K, Miyasaka N. Effect of soy lecithin on fatigue and menopausal symptoms in middle-aged women: a randomized, doubleblind, placebo-controlled study. Nutrition Journal. 2018;17:4. Hudáková A, Majerníková L. Kvalita života seniorů v kontextu ošetřovatelství. Praha: Grada Publishing, a. s.; 2013. (in Czech) Hunter MS. The Women's Health Questionnaire (WHQ): the development, standardization and application of a measure of mid-aged women's emotional and physical health. Quality of Life Research. 2000;9:733-738.

Hunter MS. The Women's Health Questionnaire (WHQ): Frequently Asked Questions (FAQ). Health and Quality of Life Outcomes. 2003;1:41.

Joseph N, Nagaraj K, Saralaya V, Nelliyanil M, Rao PJ. Assessment of menopausal symptoms among women attending various outreach clinics in South Canara District of India. Journal of Midlife Health. 2014;5(2):84-90.

Kim KH, Kang KW, Kim DI, Yoon HM, et al. Effects of acupuncture on hot flashes in perimenopausal and postmenopausal women-a multicenter randomized clinical trial. Menopause. 2010;17(2):269-280. 
Kim M, Kim AR, Park HJ, Kwon O, Kim JH, Park EJ, Baek SE, Yoo JE, Lee JH. Danggwijagyaksan for climacteric syndrome in peri- and postmenopausal women with a blooddeficiency dominant pattern: study protocol for a randomized, double-blind, placebo-controlled pilot trial. Trials. 2018;19(1):41.

Lee SW, Jo HH, Kim MR, Kwon DJ, You YO, Kim JH. Association between menopausal symptoms and metabolic syndrome in postmenopausal women. Archives of Gynecology and Obstetrics. 2012;285(2):541-548.

Lethaby A, Marjoribanks J, Kronenberg F, Roberts H, Eden J, Brown J. Phytoestrogens for menopausal vasomotor symptoms. The Cochrane Database Systematic Reviews. 2013;12:CD001395.

Liu Z, Wang Y, Xu H, Wu J, He L, Jiang JY, Yan S, Du R, Liu B. Efficacy of electroacupuncture for symptoms of menopausal transition: study protocol for a randomized controlled trial. Trials. 2014;15:242.

Mackey S, Teo SS, Dramusic V, Lee HK, Boughton M. Knowledge, attitudes, and practices associated with menopause: a multi-ethnic, qualitative study in Singapore. Health Care Women International. 2014;35(5):512-528.

Matthews VL, Knutsen SF, Beeson VL, Fraser GE. Soy milk and dairy consumption is independently associated with ultrasound attenuation of the heel bone among postmenopausal women: the Adventist Health Study-2. Nutrition Research. 2011;31(10):766-775.

Messina M. Soy foods, isoflavones, and the health of postmenopausal women. The American Journal of Clinical Nutrition. 2014;100(Suppl 1):423S-430S.

Moravcová M. Menopauza a kvalita života. PROFESE Online. 2011;4(2):6-10. (in Czech)

Moravcová M, Mareš J, Ježek S. Menopause Rating Scale validation Czech version specific instrument for assessing health-related quality of life in postmenopausal women. Ošetřovatelství a porodní asistence. 2014;5(1):36-45.

Potthoff P, Heinemann LAJ, Schneider HPG, Rosemeier HP, Hauser GA. The Menopause-Rating Skale (MRS): Methodische Standardisierung in der deutschen Bevölkerung. Zentralblatt für Gynäkologie. 2000;122(5):280-286. (in German)

Schneider HPG, Rosemeier HP, Schnitker J, Gerbsch S, Turck R. Application and factor analysis of the menopause rating scale (MRS) in a post-marketing surveillance study of Climen ${ }^{\circledR}$. Maturitas. 2000;37(2):113-124.

Schneider HPG, Heinemann LAJ, Rosemeier HP, Potthoff P, Behre HM. The Menopause Rating Scale (MRS): reliability of scores of menopausal complaints. Climacteric. 2000a;3(1):59 64.

Schneider HP, Heinemann LA, Rosemeier HP, Potthoff P, Behre HM. The Menopause Rating Scale (MRS): comparison with Kupperman index and quality of life scale SF-36. Climacteric. 2000b;3(1):50-58.

Stuenkel CA, Davis SR, Gompel A, Lumsden MA, Murad MH, Pinkerton JV, Santen RJ. Treatment of symptoms of the menopause: an Endocrine Society clinical practice guideline. The Journal of Clinical Endocrinology and Metabolism. 2015;100(11):3975-4011.

Taavoni S, Ekbatani NN, Haghani H. Postmenopausal women's quality of sleep and its related factors. Journal of Mid-Life Health. 2015;6(1):21-25.

Tranche S, Brotons C, Pascual de la Pisa B, Macías R, Hevia $\mathrm{E}$, Marzo-Castillejo M. Impact of a soy drink on climacteric symptoms: an open-label, crossover, randomized clinical trial. Gynecological Endocrinology. 2016; 32(6):477-482.

Urbánková M, Moravcová M, Dopitová D. Jak ovlivňuje menopauza kvalitu života ženy? Digitální knihovna Univerzity Pardubice; 2016. [cited 2018 Jun 11]. Available from: http://hdl.handle.net/1019/5/64751. (in Czech)

Vincent A, Barton DL, Mandrekar JN, Cha SS, Zais T, Wahner-Roedler DL, Keppler MA, Kreitzer MJ, Loprinzi C. Acupuncture for hot flashes: a randomized, sham-controlled clinical study. Menopause. 2007;14(1):45-52.

Vora R, Dangi A. Effect of yoga on menopausal symptoms in the early menopausal period: a randomized controlled trial. Indian Journal of Physiotherapy and Occupational Therapy. 2014;8(3):49-53.

Vural PI, Yangin HB. Assessing menopausal symptoms among Turkish and German women with the Menopause Rating Scale: a cross-cultural study. International Journal of Caring Sciences. 2017;10(2):979-986.

Wariso BA, Guerrieri GM, Thompson K, Koziol DE, Martinez PE, Rubinow DR, Schmidt PJ. Depression during the menopause transition: impact on quality of life, social adjustment, and disability. Archives of Women's Mental Health. 2017;20(2):273-282. 